\title{
KARAKTERISTIK FISIK, KIMIA, DAN ORGANOLEPTIK MIE MOSAF (MODIFIED SATOIMO FLOUR) (Colocasia esculenta)
}

\section{THE CHARACTERISTICS OF PHYSICAL, CHEMICAL, AND ORGANOLEPTICS OF MOSAF (MODIFIED SATOIMO FLOUR) NOODLE}

\author{
Eliantosi $^{1}$, Darius ${ }^{1}$ \\ 1) Program Studi Teknologi Pertanian Fakultas Pertanian UNIVED
}

\begin{abstract}
ABSTRAK
Satoimo atau biasa dikenal dengan talas Jepang memiliki nama latin Colocasia esculenta var Antiquorum. Talas Jepang kaya akan Hyaluronic Acid (HA), suatu zat yang diproduksi alami dalam tubuh dan menghasilkan kolagen alami. Tepung talas tergolong halus dan mudah dicerna berguna untuk pembuatan kue kering, kue basah, roti dan mie. Mie merupakan salah satu produk yang banyak disukai oleh semua kalangan masyarakat. Telah dilakukan penelitian yang bertujuan untuk menganalisis karakteristik fisik, kimia, dan organoleptik mie mosaf (Colocasia esculenta). Perlakuan yang dilakukan dalam penelitian ini adalah perbandingan tepung terigu : tepung mosaf dengan variasi $450 \mathrm{~g}: 50 \mathrm{~g} ; 400 \mathrm{~g}$ : $100 \mathrm{~g} ; 350 \mathrm{~g}: 150 \mathrm{~g} ; 300 \mathrm{~g}: 200 \mathrm{~g}$; dan $250 \mathrm{~g}$ : $250 \mathrm{~g}$. Analisa dalam penelitian ini meliputi analisa kandungan serat, elastisitas dan uji organoleptik (warna, rasa dam tekstur) mie basah mosaf. Hasil penelitian menunjukkan bahwa semakin tinggi konsentrasi tepung mosaf yang ditambahkan, maka kadar serat mie menjadi semakin tinggi namun elastisitasnya semakin turun, sedangkan tingkat kesukaan konsumen terhadap parameter warna, rasa dan tekstur semakin turun, dengan tingkat toleransi komposisi tepung terigu : tepung mosaf $400 \mathrm{~g}: 100 \mathrm{~g}$.
\end{abstract}

Kata kunci : mie, satoimo, mosaf

\begin{abstract}
Satoimo rich in Hyaluronic Acid ( HA), a substance produced naturally in the body and produce natural collagen. Taro flour relatively smooth and easy to digest useful for the preparation of pastries, cakes, breads and noodles. Noodle is one of the many products that are favored by all the community. Has conducted research aimed to analyze the characteristics of the physical, chemical and organoleptic noodles mosaf ( Colocasia esculenta). The treatment is done in this study is a comparison of wheat flour: flour mosaf with variations $450 \mathrm{~g}: 50 \mathrm{~g} ; 400 \mathrm{~g}: 100 \mathrm{~g} ; 350 \mathrm{~g}: 150 \mathrm{~g} ; 300 \mathrm{~g}: 200 \mathrm{~g}$; and 250 $g: 250 \mathrm{~g}$. The analysis in this study includes the analysis of the fiber content, elasticity and organoleptic (color, taste, texture dam) mosaf wet noodle. The results showed that the higher concentration mosaf flour is added, then the noodles fiber content becomes higher but getting lower elasticity, whereas the level of consumer preferences of the parameters of color, flavor and texture of getting down, the tolerance level of the composition of wheat flour : $400 \mathrm{~g}$ flour mosaf : $100 \mathrm{~g}$.
\end{abstract}

Keywords : noodles, satoimo, mosaf 


\section{PENDAHULUAN}

Satoimo atau biasa dikenal dengan talas jepang memiliki nama latin Colocasia esculenta var Antiquorum. Sebagai bahan pangan talas Jepang dikonsumsi sebagai sumber kalsium dan bahan makanan yang memiliki kalori terbilang tinggi dan memiliki jumlah karbohidrat yang rendah. Talas Jepang kaya akan Hyaluronic Acid (HA), suatu zat yang diproduksi alami dalam tubuh dan menghasilkan kolagen alami. Talas Jepang juga mengandung serat yang baik untuk pencernaan, sehingga dapat menjadi bahan campuran pembuat agaragar atau jelly, campuran es krim biskuit, dan sup. Modifikasi sebagai perubahan struktur molekul dari pati dapat dilakukan secara kimia, fisika maupun enzimatis (Subagio A, 2007). Modifikasi dimaksudkan sebagai perubahan struktur molekul yang dapat dilakukan secara kimia, fisik maupun enzimatis. Pati alami dapat dibuat menjadi pati termodifikasi dengan sifat sifat yang dikehendaki atau sesuai dengan kebutuhan (Alsuhendra dan Ridawati, 2009).

Mie merupakan salah satu produk yang banyak disukai oleh semua kalangan masyarakat. Ada banyak jenis-jenis mie yaitu mie basah, mie kering dan mie instant. Mie tergolong sebagai produk pasta yaitu suatu produk bahan makanan dengan mencampurkan tepung terigu dan air serta berbagai bahan tambahan seperti garam, telur dan bahan tambahan lainnya (Astawan, 2006). Sejauh ini penelitian tentang pengolahan mie yang menggunakan bahan campuran dari umbi talas khususnya satoimo atau talas Jepang belum banyak dilakukan, sehingga perlu dilakukan penelitian tentang karakteristik fisik, kimia dan organoleptik mie yang terbuat dari bahan campuran terigu dan tepung mosaf.

\section{METODE PENELITIAN}

\section{Bahan dan Alat}

Alat dalam proses pengolahan mie yaitu baskom, pisau, wajan, sendok besi, timbangan, pencetak mie dan talanan. Bahan yang dibutuhkan dalam penelitian ini yaitu satoimo (talas Jepang), tepung terigu, stater bimo-CF, garam, telur,air, minyak goreng. Bahan untuk analisa yaitu $\mathrm{H}_{2} \mathrm{SO}_{4}$, zat anti buih, $\mathrm{K}_{2} \mathrm{SO}_{4}$, dan alkohol

\section{Proses Pengolahan Tepung Mosaf}

Psoses pengolahan tepung mosaf meliputi pengupasan dan pencucian, perajangan, fermentasi dengan Starter $B I M O-C F$, pengepresan, pengeringan, penghalusan dan pengayakan. Proses pengolahan mie mosaf yaitu 
Penimbangan tepung terigu, pencampuran bahan, pengulenan, pembentukan lembaran, perebusan mie, pendinginan selama 10 menit. Rancangan yang digunakan dalam penelitian ini yaitu Rancangan Acak Lengkap (RAL) dengan faktor tunggal yaitu perbandingan tepung terigu dan tepung mosaf. Analisa penelitian yaitu elastisitas mie mosaf, kandungan serat dan dilakukan uji organoleptik dengan parameter penilaian terhadap warna, rasa dan tekstur (Kartika dkk, 1998).

\section{HASIL DAN PEMBAHASAN}

\section{Kandungan Kadar Serat Mie Mosaf \\ Basah}

Nilai rerata hasil analisis terhadap kandungan serat mie basah dengan perlakuan perbandingan penggunaan tepung terigu dan tepung mosaf (450 gr : 50 gr, 400 gr : 100 gr, 350 gr : 150 gr, $300 \mathrm{gr}: 200 \mathrm{gr}$ dan $250 \mathrm{gr}: 250 \mathrm{gr}$ ) dapat dilihat pada tabel 1. Hasil analisa terhadap mie basah menunjukkan terdapat perbedaan yang nyata pada taraf signifikan 5\% terhadap kandungan kadar serat mie basah dengan perlakuan perbandingan penggunaan tepung terigu dan tepung mosaf. Kadar serat mie basah yang dihasilkan dengan perbandingan tepung terigu dan tepung mosaf dapat dipengaruhi oleh besarnya serat dalam bahan makanan dan formulasi bahan yang digunakan. Pada pembuatan mie basah tepung terigu yang digunakan disubstitusi dengan tepung mosaf dimana kandungan serat satoimo sebesar $16,18 \%$ dan kandungan serat tepung terigu sebesar 0,8\% (Rahayu, R. 2001). Kandungan serat mie basah pada umumnya sebesar $0,18 \%$.

\section{Elastisitas Mie Mosaf Basah}

Nilai rerata hasil analisis terhadap waktu putus mie basah dengan perlakuan perbandingan penggunaan tepung terigu dan tepung mosaf (450 gr : 50 gr, 400 gr : 100 gr, 350 gr : 150 gr, 300 gr : 200 gr dan 250 gr : 250 gr) dilihat pada tabel 2.

Hasil analisa terhadap mie basah pada tabel 2 menunjukkan terdapat perbedaan yang nyata pada taraf signifikan 5\%.

Elastisitas mie basah dapat dipengaruhi oleh semakin tingginya penggunaan tepung terigu pada pengolahan mie. Hal ini didukung oleh pendapat Anonim (2006) yang menyatakan bahwa subtitusi atau campuran tepung lain pada produk mie yang semakin tinggi menyebabkan produk mie akan mudah putus karena kandungan gluten menurun. Gluten adalah protein yang terdapat pada terigu. 
Tabel 1. Nilai Rata-Rata Analisa Kandungan Serat Mie Mosaf Basah

\begin{tabular}{cc}
\hline Perlakuan & Kandungan Serat $(\%)$ \\
\hline Tepung terigu : Tepung mosaf & \\
\hline $450: 50$ & $1,27^{\mathrm{d}}$ \\
$400: 100$ & $1,34^{\mathrm{c}}$ \\
$350: 150$ & $1,96^{\mathrm{b}}$ \\
$300: 200$ & $2,14^{\mathrm{a}}$ \\
$250: 250$ & $1,98^{\mathrm{b}}$ \\
\hline
\end{tabular}

Ket : Angka yang diikuti oleh kode huruf yang berbeda menunjukkan adanya perbedaan yang nyata pada taraf signifikansi 5\%

Tabel 2. Nilai Rata-Rata Analisa Elastisitas Mie Mosaf Basah

\begin{tabular}{cc}
\hline Perlakuan & Nilai Elastisitas (detik) \\
\cline { 1 - 1 } Tepung terigu : Tepung mosaf & $20,41^{\mathrm{a}}$ \\
$450: 50$ & $18,80^{\mathrm{b}}$ \\
$400: 100$ & $17,75^{\mathrm{b}}$ \\
$350: 150$ & $14,10^{\mathrm{c}}$ \\
$300: 200$ & $10,44^{\mathrm{d}}$ \\
$250: 250$ &
\end{tabular}

Ket : Angka yang diikuti oleh kode huruf yang berbeda menunjukkan adanya perbedaan yang nyata pada taraf signifikansi $5 \%$.

Tabel 3. Nilai Rata-Rata Sensoris Rasa Mie Mosaf Basah

\begin{tabular}{cc}
\hline Perlakuan & Rasa \\
\hline Tepung terigu : Tepung mosaf & \\
\hline $450: 50$ & $3,45^{\mathrm{a}}$ \\
$400: 100$ & $3,55^{\mathrm{a}}$ \\
$350: 150$ & $2,65^{\mathrm{b}}$ \\
$300: 200$ & $2,65^{\mathrm{b}}$ \\
$250: 250$ & $2,05^{\mathrm{c}}$ \\
\hline
\end{tabular}

Ket : Angka yang diikuti oleh kode huruf yang berbeda menunjukkan adanya perbedaan yang nyata pada taraf signifikansi $5 \%$. Ket Skala : $1=$ sangat tidak suka; $2=$ tidak suka; 3 $=$ agak suka; $4=$ suka; $5=$ sangat suka

Tabel 4. Nilai Rata-Rata Sensoris Warna Mie Mosaf Basah

\begin{tabular}{cc}
\hline Perlakuan & Warna \\
\hline Tepung terigu : Tepung mosaf & \\
\hline $450: 50$ & $3,10^{\mathrm{a}}$ \\
$400: 100$ & $3,00^{\mathrm{a}}$ \\
$350: 150$ & $2,75^{\mathrm{b}}$ \\
$300: 200$ & $2,90^{\mathrm{b}}$ \\
$250: 250$ & $2,70^{\mathrm{b}}$ \\
\hline
\end{tabular}

Ket : Angka yang diikuti oleh kode huruf yang berbeda menunjukkan adanya perbedaan yang nyata pada taraf signifikansi 5\%. Ket Skala : $1=$ sangat tidak suka; $2=$ tidak suka; $3=$ agak suka; $4=$ suka; $5=$ sangat suka 
Tabel 5. Nilai Rata-Rata Sensoris Tekstur Mie Mosaf Basah

\begin{tabular}{cc}
\hline Perlakuan & Tekstur \\
\hline Tepung terigu : Tepung mosaf & \\
\hline $450: 50$ & $4,05^{\mathrm{a}}$ \\
$400: 100$ & $3,80^{\mathrm{b}}$ \\
$350: 150$ & $2,20^{\mathrm{c}}$ \\
$300: 200$ & $2,25^{\mathrm{c}}$ \\
$250: 250$ & $1,85^{\mathrm{c}}$ \\
\hline
\end{tabular}

Ket : Angka yang diikuti oleh kode huruf yang berbeda menunjukkan adanya perbedaan yang nyata pada taraf signifikansi $5 \%$. Ket Skala : $1=$ sangat tidak suka; $2=$ tidak suka; $3=$ agak suka; 4 = suka; 5 = sangat suka

\section{Uji Sensoris Rasa Mie Mosaf Basah}

Nilai rerata hasil uji sensoris rasa mie basah dengan perlakuan perbandingan penggunaan tepung terigu dan tepung mosaf (450 gr : $50 \mathrm{gr}, 400 \mathrm{gr}: 100 \mathrm{gr}$, 350 gr : 150 gr, 300 gr : 200 gr dan 250 gr : 250 gr) dilihat pada tabel 3.

Hasil analisa terhadap mie basah pada tabel 3 menunjukkan terdapat perbedaan yang nyata pada taraf signifikan 5\%. Rasa mie basah dengan perlakuan perbandingan penggunaan tepung tapioka dan tepung mosaf dapat dipengaruhi oleh penambahan tepung mosaf yang semakin tinggi, dimana semakin tinggi penambahan tepung mosaf penilaian panelis berada pada skala tidak suka. Mie basah dengan rasa tepung mosaf masih terasa asing oleh panelis sehingga tidak disukai. Selain itu rasa mie basah ditimbulkan akibat penggunaan stater dalam proses penggolahan tepung mosaf, dimana menurut Subagio, (2007) bakteri asam laktat pada stater mampu mendegradasi gula yang terkandung dalam media pertumbuhannya menjadi gula sederhana, mendegradasi protein dan peptida menjadi asam amino. Senyawa asam ini akan bercampur dengan tepung sehinggga ketika tepung tersebut diolah akan menghasilkan aroma dan cita rasa khas (Adebowale, et al, 2002).

\section{Uji Sensoris Warna Mie Mosaf Basah}

Nilai rerata hasil uji sensoris warna mie basah dengan perlakuan perbandingan penggunaan tepung terigu dan tepung mosaf (450 gr : 50 gr, 400 gr : 100 gr, 350 gr : 150 gr, 300 gr : 200 gr dan 250 gr : 250 gr) dilihat pada tabel 4.

Hasil analisa terhadap mie basah pada tabel 4 menunjukkan perbedaan nyata pada taraf signifikan 5\%. Warna mie basah yang dihasilkan yaitu agak kecoklatan yang disebabkan oleh warna dari satoimo, sehingga dengan semakin tinggi penambahan tepung mosaf 
mempengaruhi warna mie. Warna coklat pada tepung talas diakibatkan proses pengeringan. Warna bahan pangan yang dikeringkan pada umumnya berubah menjadi coklat. Perubahan tersebut disebabkan oleh reaksi browning non enzimatik yakni reaksi antara asam organik dengan gula pereduksi dan antara asam-asam amino dengan gula pereduksi (Anonim, 2011), selain itu warna coklat pada mie disebabkan oleh warna dari tepung mosaf yang diakibatkan adanya aktivitas enzim polyphenol oksidase (PPO) yang membentuk warna coklat (Winarno, F.G, 2002).

\section{Uji Sensoris Tekstur Mie Mosaf Basah}

Nilai rerata hasil uji sensoris tekstur mie basah dengan perlakuan perbandingan penggunaan tepung terigu dan tepung mosaf (450 gr : 50 gr, 400 gr : 100 gr, 350 gr : 150 gr, 300 gr : 200 gr dan 250 gr : 250 gr) dilihat pada tabel 5 .

Hasil analisa terhadap mie basah pada tabel 5 menunjukkan terdapat perbedaan yang nyata pada taraf signifikan 5\%. Anonim (2006) menyatakan bahwa subtitusi atau campuran tepung lain pada produk mie yang semakin tinggi menyebabkan produk mie akan mudah putus karena kandungan gluten menurun, sehingga dengan semakin tinggi penambahan tepung mosaf maka tekstur mie menjadi lebih mudah putus.

\section{SIMPULAN}

Hasil penelitian menunjukkan bahwa semakin tinggi konsentrasi tepung mosaf yang ditambahkan, maka kadar serat mie menjadi semakin tinggi namun elastisitasnya semakin turun, sedangkan tingkat kesukaan konsumen terhadap parameter warna, rasa dan tekstur semakin turun, dengan tingkat toleransi komposisi tepung terigu : tepung mosaf $400 \mathrm{~g}: 100 \mathrm{~g}$.

\section{DAFTAR PUSTAKA}

Adebowale, K.O., Afolabi, T.A., dan Lawal, O.S. 2002. "Isolation, Chemical Modification and Physicochemical Characterisation of Bambarra Groundnut (Voandzeia subterranean) Starch and Flour" dalam Food Chemistry 78:305-311

Anonim, 2006. Teknologi Mie Instan. http://www.ebookpangan.com.Dia kses 11 Januari 2009

Anonim. 2007.Uji Organoleptik. http://rizkyunsyah.blogspot.com. Diakses, 23 Desember 2013

Alsuhendra dan Ridawati. 2009. Pengaruh Modifikasi secara Pregelatinisasi, Asam dan Enzimatis terhadap Sifat Fungsional Tepung Umbi Gembili (Dioscorea esculenta). Jurnal PS Tata Boga Jurusan IKK FT UNJ: 4-5.

Astawan, M., 2006. Membuat Mie dan Bihun. Penebar Swadaya, Jakarta. 
Kartika, B., P. Hastuti dan W. Supartono. 1998. Pedoman Uji Indrawi Bahan Pangan PAU Pangan PAU Pangan dan Gizi Universitas Gaja Mada, Yogyakarta.

Rahayu, R. 2001. Kekenyalan Tepung Terigu. Institut Pertanian Bogor. Bogor.

Subagio A. 2007. Industrialisasi Modified Cassava Flour
(MOCAF) sebagai Bahan Baku Industri Pangan untuk Menunjang Diversifikasi Pangan Pokok Nasional. Jember : Fakultas Teknologi Pertanian, Universitas Jember.

Winarno, F.G. 2002. Kimia Pangan dan Gizi, Gramedia Pustaka Utama. Jakarta. 